\title{
Notaris yang Melakukan Rangkap Jabatan sebagai Dosen
}

\author{
Agus Setiawan \\ Doctoral Student, Faculty of Law, Parahyangan Catholic University, Indonesia \\ agillarius@gmail.com \\ Submitted: 2017-11-24; Reviewed: 2018-03-02; Accepted: 2018-04-30
}

\begin{abstract}
Notariy is public official, do its profession according to Law Number 2 of 2014 on Amandement of Law Number 30 of 2004 on Notary (Law of Notary) and Code of Conduct of Notary. Notary is required to obey the law including prohibition to double position as civil official, advocate, legal officer and others. Other than those, notary mostly work as lecturer and it cause question whether a notary may work in double as lecturer. This question may be debatable and has an affect to legal certaincy. This article aims to examine wheter a notary who also work as lecturer has violate the law on notary and code of conduct of notary. This research is normative juridical, using secondary data consisting primary, secondary and tertier legal material. This article is analyzed qualitatively. This article showed that carry on double jobs as notary and lecturer can be justified and did not violate Law on Notary and code of conduct of notary as long as he/she works in any college established by foundation not public college.
\end{abstract}

Keywords: Double occupation; lecturer; notary.

\section{PENDAHULUAN}

Pada beberapa perguruan tinggi, khususnya sekolah tinggi hukum atau perguruan tinggi yang memiliki fakultas hukum atau program pasca sarjana; banyak dijumpai para praktisi di bidang hukum, seperti : Notaris, Advokat, Hakim, dan pengemban profesi hukum atau praktisi hukum lain yang dinilai mumpuni secara keilmuan dan memiliki panggilan di bidang akademik, menjadi dosen atau tenaga pengajar pada sekolah tinggi hukum atau fakultas hukum atau program pasca sarjana tersebut. Hal ini tentunya sah-sah saja selama tidak ada larangan, baik yang ditetapkan oleh peraturan perundang-undangan maupun kode etik yang mengatur perilaku dan sikap moral yang diberlakukan secara khusus bagi profesi hukum yang bersangkutan untuk mengemban jabatan rangkap sebagai dosen/tenaga pengajar di institusi-institusi pendidikan tinggi tersebut.

Kontribusi yang sekiranya diharapkan dapat disumbangsihkan oleh dosen yang juga praktisi pengemban profesi hukum, antara lain adalah adanya pendekatan dan pemahaman yang seimbang antara dunia keilmuan hukum dengan dunia praktik 
hukum pada kenyataannya, antara das sollen dengan das sein. Para peserta didik diharapkan mendapatkan pemahaman antara lain mengenai: apa yang menjadi kaidah hukum dan fakta hukumnya, bagaimana hukum diterapkan pada suatu kondisi tertentu, bagaimana penegak dan pelaku hukum dalam melaksanakan hukum, serta bagaimana masyarakat merespon hukum tersebut, dan lain sebagainya.

Pada fenomena rangkap jabatan yang dilakukan oleh para pengemban profesi hukum ini, ada pula para praktisi pengemban profesi hukum yang mengemban jabatan sebagai Notaris, ternyata melakukan rangkap jabatan sebagai dosen atau tenaga pegajar di suatu perguruan tinggi, baik di fakultas hukum, program magister kenotariatan atau program pasca sarjana lainnya. Pengembanan jabatan rangkap sebagai Notaris dan juga sebagai dosen atau tenaga pengajar tersebut terkadang menimbulkan keraguan mengenai boleh atau tidaknya rangkap jabatan sebagai dosen atau tenaga pengajar tersebut dilakukan. Keraguan ini berpotensi menimbulkan suatu perdebatan yang terkadang berujung pada kondisi ketidak-pastian hukum.

Identifikasi masalah utama sehubungan dengan rangkap jabatan baik sebagai Notaris maupun sebagai dosen atau tenaga pengajar tersebut adalah: bagaimana tinjauan yuridis mengenai pengemban jabatan Notaris yang melakukan rangkap jabatan dengan menjadi dosen atau tenaga pengajar, apakah dapat dikategorikan telah melakukan suatu pelanggaran terhadap peraturan perundang-undangan yang mengatur mengenai jabatan Notaris dan Kode Etik Ikatan Notaris Indonesia?.
Sebuah pertanyaan yang boleh dikatakan cukup membuat para pengemban profesi Notaris dan yang berprofesi sebagai Dosen saling berargumen mengingat adanya ketentuan peraturan perundangundangan mengenai Jabatan Notaris dan Kode Etik Ikatan Notaris Indonesia, serta sanksi yang tertera dalam Pasal 85 Undangundang Nomor 30 Tahun 2004 Tentang Jabatan Notaris dan Kode Etik Ikatan Notaris Indonesia dari mulai teguran lisan, teguran tertulis, pemberhentian sementara, pemberhentian dengan hormat atau sampai dengan pemberhentian dengan tidak hormat.

Terlepas dari reaksi apapun terhadap pertanyaan di atas, pengembanan jabatan rangkap tesebut menurut pendapat penulis merupakan suatu fenomena yang berpotensi menjadi masalah hukum tersendiri bila tidak segera diberikan suatu kepastian hukum terhadapnya. Oleh karenanya, dalam tulisan di bawah ini, penulis akan mencoba melakukan pengkajian terhadap pertanyaan utama tersebut untuk berupaya memberikan suatu sumbangan pemikiran berupa argumentasi yuridis tersendiri yang dibentuk atau didasari pada analisis terhadap beberapa pertanyaan yuridis pendukung yang tentunya hasilnya nanti sangat terbuka untuk dilakukan kontra argumen atau pengkajian yang lebih luas dan lebih dalam terhadapnya.

\section{PEMBAHASAN \\ Notaris dan Kewenangannya}

Keberadaan pengaturan mengenai 'Pejabat Umum' dan 'Akta Otentik' dapat ditemukan pada Pasal 1868 Kitab UndangUndang Hukum Perdata (KUHPdt), yang menyebutkan bahwa: 'Akta otentik ialah 
suatu akta yang di dalam bentuk yang ditentukan oleh undang-undang dibuat oleh atau dihadapan Pejabat Umum yang berwenang untuk itu ditempat dimana akta dibuatnya'. Pasal 1868 KUHPdt memang tidak menjelaskan mengenai siapa yang dimaksud dengan 'Pejabat Umum'; akan tetapi bila kita menggunakan penafsiran sistematis antara Pasal 1 angka 1 UUJN terhadap Pasal 1868 KUHPdt, maka dalam kaidah hukum tersebut dapat ditafsirkan bahwa yang dimaksud dengan 'Pejabat Umum' di dalam Pasal 1868 KUHPdt tidak lain adalah 'Notaris' itu sendiri. Notaris merupakan perpanjangan tangan dari pemerintah dalam hal ini negara, di mana negara telah memberikan kepercayaan kepada Notaris untuk menjalankan sebagian urusan atau tugas negara, khususnya dalam bidang hukum perdata ${ }^{1}$.

Notaris adalah pejabat umum yang berwenang untuk membuat akta otentik dan memiliki kewenangan lainnya sebagaimana dimaksud dalam UndangUndang ini atau berdasarkan undangundang lainnya ${ }^{2}$. Adapun yang dimaksud dengan 'Undang-Undang ini' pada definisi di atas tidak lain adalah Undang-Undang Nomor 2 Tahun 2014 Tentang Perubahan Atas Undang-Undang Nomor 30 Tahun 2004 Tentang Jabatan Notaris ('UUJN No.

\footnotetext{
${ }^{1}$ Santia Dewi dan R.M. Fauwas Diradja, Panduan Teori dan Praktik Notaris, Penerbit Pustaka Yustisia, Yogyakarta, 2011, hlm. 8.

${ }^{2}$ Definisi otentik dari konsep 'Notaris' dinyatakan dalam pasal 1 angka 1 Undang-Undang Nomor 2 Tahun 2014 Tentang Perubahan Atas UndangUndang Nomor 30 Tahun 2004 Tentang Jabatan Notaris.

${ }^{3}$ Konsep 'pengemban' dalam tulisan ini diambil dari konsep 'pengembanan hukum'; sebuah konsep yang diperkenalkan oleh B. Arief Sidharta, yang dimaknai sebagai kegiatan manusia yang berkenaan dengan adanya dan berlakunya hukum. Konsep 'pengembanan hukum' adalah terjemahan dari konsep 'Rechtsbeoefening' (D.H.M. Meuwissen,
}

2/2014'). Sedangkan yang dimaksud dengan 'undang-undang lainnya' adalah peraturan perundang-undangan yang berlaku, selain UUJN No. 2/2014, yang juga memuat kewenangan dan perintah kepada Notaris untuk membuat akta notaris-nya atau hal lain sesuai tugas pokok dan kewenangannya berdasarkan peraturan perundang-undangan. 'Undang-undang lainnya' tersebut diantaranya adalah Undang-Undang Nomor 42 Tahun 1999 Tentang Jaminan Fidusia, Undang-Undang Nomor 40 Tahun 2007 Tentang Perseroan Terbatas, Undang-Undang Nomor 20 Tahun 2011 Tentang Rumah Susun, dan lain sebagainya.

Menyimak definisi otentik 'Notaris', tersirat pemaknaan bahwa Notaris adalah profesi yang bila diklasifikasikan termasuk dalam pengemban ${ }^{3}$ hukum praktis ${ }^{4}$ yang tentunya memiliki tugas pokok dan kewenangan tersendiri berdasarkan peraturan perundang-undangan. Sebagaimana yang disampaikan oleh Wawan Setiawan (Ketua Ikatan Notaris Indonesia periode 1992 - 1995), tugas pokok pengemban profesi Notaris adalah: “... menjalankan (sebagian dari) kekuasaan Negara, untuk membuat alat bukti tertulis dan otentik, dalam bidang hukum perdata." 5 Berdasarkan definisi resmi

Vijf Stellingen over Rechtsfilosofie dalam Een Beel Van Recht. Ars Aequi. 1979: 22 - 32.).

${ }^{4}$ Konsep 'pengemban hukum praktis' diambil dari konsep 'pengembanan hukum praktis'. B. Arief Shidharta memaknai 'pengembanan hukum praktis' sebagai seluruh kegiatan untuk mewujudkan hukum dalam kenyataan kehidupan sehari-hari, yang meliputi kegiatan pembentukan hukum, penemuan hukum, dan bantuan hukum. Lihat: B. Arief Sidharta, Pengembanan Hukum dewasa ini di Indonesia, makalah yang tidak diterbitkan, terdapat pada Fakultas Hukum Universitas Katolik Parahyangan, 2011, hlm. 1.

${ }^{5}$ A.A. Andi Prajitno, Pengetahuan Praktis Tentang Apa Dan Siapa Notaris Di Indonesia?, Cet. I, 
sebagaimana telah diuraikan sebelumnya, kewenangan pengemban profesi Notaris tidak lain berhubungan dengan pembuatan bukti-bukti tertulis dalam bentuk akta otentik, beserta dengan segala sesuatu yang merupakan turunan dari pembuatan akta otentik tersebut serta kewenangan lain berdasarkan peraturan perundangundangan.

Secara terinci, kewenangan pengemban profesi Notaris dinyatakan dalam Pasal 15 UUJN No. 2/2014 yang berbunyi:

1. "Notaris berwenang membuat Akta autentik mengenai semua perbuatan, perjanjian, dan penetapan yang diharuskan oleh peraturan perundang-undangan dan/atau yang dikehendaki oleh yang berkepentingan untuk dinyatakan dalam Akta autentik, menjamin kepastian tanggal pembuatan Akta, menyimpan Akta, memberikan grosse, salinan dan kutipan Akta, semuanya itu sepanjang pembuatan Akta itu tidak juga ditugaskan atau dikecualikan kepada pejabat lain atau orang lain yang ditetapkan oleh undangundang.

2. Selain kewenangan sebagaimana dimaksud pada ayat (1), Notaris berwenang pula:
a. mengesahkan tanda tangan dan menetapkan kepastian tanggal surat di bawah tangan dengan mendaftar dalam buku khusus;
b. membukukan surat di bawah tangan dengan mendaftar dalam buku khusus;
c. membuat kopi dari asli surat di

bawah tangan berupa salinan yang memuat uraian sebagaimana ditulis dan digambarkan dalam surat yang bersangkutan;

d. melakukan pengesahan kecocokan fotokopi dengan surat aslinya;

e. memberikan penyuluhan hukum sehubungan dengan pembuatan Akta;

f. membuat Akta yang berkaitan dengan pertanahan; atau

g. membuat Akta risalah lelang.

3. Selain kewenangan sebagaimana dimaksud pada ayat (1) dan ayat (2), Notaris mempunyai kewenangan lain yang diatur dalam peraturan perundang-undangan."

Pada intinya pengemban profesi Notaris ditugaskan untuk menjalankan sebagian dari kekuasaan negara dalam bidang hukum perdata dan untuk itu kepadanya diberikan kewenangan tertentu, termasuk untuk membuat alat bukti tertulis dalam bentuk akta otentik.

\section{Jabatan yang Tidak Diperbolehkan untuk Dirangkap oleh Notaris}

Penentuan jabatan rangkap apa yang tidak boleh dirangkap oleh pengemban jabatan Notaris bukanlah hal yang sulit untuk dijawab. Pasal 17 huruf c, d, e, f, g, h, dan i UUJN No. 2/2014 secara eksplisit telah menyebutkan bahwa Notaris dilarang:merangkap sebagai pegawai negeri, merangkap jabatan sebagai pejabat negara, merangkap jabatan sebagai advokat, merangkap jabatan sebagai 
pemimpin atau pegawai badan usaha milik negara, badan usaha milik daerah atau badan usaha swasta, merangkap jabatan sebagai Pejabat Pembuat Akta Tanah di luar wilayah jabatan Notaris, menjadi Notaris Pengganti, melakukan pekerjaaan lain yang bertentangan dengan norma agama, kesusilaan, atau kepatutan yang dapat mempengaruhi kehormatan dan martabat jabatan Notaris.

Pengemban jabatan Notaris yang melanggar ketentuan tersebut dan melakukan jabatan rangkap yang dilarang dalam Pasal 17 huruf c, d, e, f, g, h, dan i UUJN No. 2/2014 tersebut, berdasarkan Pasal 85 UUJN No. 30/2004 dapat dikenakan sanksi berupa : teguran lisan, teguran tertulis, pemberhentian sementara, pemberhentian dengan hormat, pemberhentian dengan tidak hormat. Sebagaimana disebutkan di atas, kaidah hukum yang tertuang dalam UUJN secara eksplisit telah mengatur mengenai rangkap jabatan yang dilarang untuk diemban oleh Notaris berikut sanksinya jika terjadi pelanggaran terhadapnya. Selanjutnya di bawah ini akan dilihat dari persepsi kaidah moral yang berlaku bagi Notaris.

Kode Etik Ikatan Notaris Indonesia adalah merupakan seluruh kaidah moral yang ditentukan oleh Perkumpulan Ikatan Notaris Indonesia yang berlaku bagi serta wajib ditaati oleh setiap dan semua anggota Perkumpulan dan semua orang yang menjalankan tugas jabatan sebagai Notaris, termasuk para Pejabat Sementara Notaris, Notaris Pengganti dan Notaris Pengganti Khusus. Berdasarkan Pasal 3 Kode Etik Ikatan Notaris Indonesia disebutkan pada intinya bahwa: Notaris dan orang lain yang memangku dan menjalankan jabatan Notaris wajib: memiliki moral, akhlak, serta kepribadian yang baik; menghormati dan menjunjung tinggi harkat dan martabat jabatan Notaris; melakukan perbuatanperbuatan yang secara umum disebut sebagai kewajiban untuk ditaati dan dilaksanakan antara lain namun tidak terbatas pada ketentuan yang tercantum dalam peraturan perundang-undangan yang mengatur mengenai jabatan Notaris.

Sehubungan dengan larangan mengenai jabatan rangkap bagi Notaris sebagaimana diatur dalam Pasal 17 UUJN No. 2/2014, diatur pula dalam Kode Etik Ikatan Notaris Indonesia; maka dalam hal ini dapatlah dikatakan bahwa pelanggaran terhadap larangan jabatan rangkap bagi pengemban jabatan Notaris juga merupakan pelanggaran terhadap Kode Etik Ikatan Notaris Indonesia. Oleh karenanya, Dewan Kehormatan Perkumpulan Ikatan Notaris Indonesia sesuai kewenangannya masingmasing, berdasarkan Pasal 6 Kode Etik Ikatan Notaris Indonesia dapat melakukan pemeriksaan bagi Notaris yang diduga melakukan pelanggaran dan menjatuhkan sanksi kepada pengemban jabatan Notaris yang terbukti melanggar Kode Etik Ikatan Notaris Indonesia, yang sanksinya dapat berupa: Teguran, peringatan, Schorsing (pemecatan sementara), Onzetting (pemecatan), atau pemberhentian dengan tidak hormat. Notaris dituntut untuk senantiasa "berjalan" dalam kaidah hukum dan kaidah moral yang telah ditentukan baginya. Herlien Budiono ${ }^{6}$ mengatakan bahwa bekal intelektualitas diperoleh

\footnotetext{
6 Herlien Budiono, Kumpulan Tulisan Hukum Perdata di Bidang Kenotariatan, Buku Kedua, Bandung: Citra Aditya Bakti, 2010, hlm.178.
} 
notaris dari pendidikan formal, magang dan pengalaman di dalam praktik. Sedangkan bekal spiritualitas timbul dari dalam diri sendiri, dari dalam hati nurani (conscience), dan terjabarkan sebagai perilaku di dalam menjalankan jabatan notaris sesuai dengan UUJN dan Kode Etik Notaris.

\section{RANGKAP JABATAN SEBAGAI NOTARIS DAN SEBAGAI DOSEN}

Untuk menjawab pertanyaan: “Apakah Notaris yang melakukan rangkap jabatan sebagai dosen/tenaga pengajar adalah termasuk Notaris yang telah melakukan pelanggaran terhadap Undang-Undang Nomor 30 Tahun 2004 Tentang Jabatan Notaris dan Kode Etik Ikatan Notaris Indonesia khususnya yang mengatur mengenai larangan rangkap jabatan?"; di bawah ini akan terlebih dahulu di analisa mengenai pendirian dari suatu Perguruan Tinggi sebagai tempat di mana para dosen/tenaga pengajar melakukan kegiatannya. Analisa ini sesungguhnya berguna untuk menentukan mengenai eksistensi dari perguruan tinggi tersebut apakah suatu badan usaha ataukah bukan, yang nantinya akan berguna untuk menentukan apakah para profesional dan pekerja yang bekerja pada perguruan tinggi tersebut adalah pegawai dari suatu badan usaha atau bukan, apakah para pengemban jabatan struktural yang ada pada perguruan tinggi tersebut adalah pemimpin suatu badan usaha atau bukan, dan analisa lain yang sekiranya dapat dikembangkan selanjutnya.

Dilihat dari persepsi pendiriannya; Pasal 60 Undang-Undang Nomor 12 Tahun 2012 Tentang Perguruan Tinggi pada intinya menyebutkan bahwa Perguruan
Tinggi Negeri didirikan oleh Pemerintah, sedangkan Perguruan Tinggi Swasta didirikan oleh Masyarakat dengan membentuk badan penyelenggara berbadan hukum yang berprinsip nirlaba dan wajib memperoleh izin Menteri. Badan penyelenggara berbadan hukum yang dimaksud, dapat berbentuk yayasan, perkumpulan, dan bentuk lain sesuai dengan ketentuan peraturan perundangundangan. Adapun yang dimaksud dengan "prinsip nirlaba" berdasarkan penjelasan Pasal 60 Undang-Undang Nomor 12 Tahun 2012 Tentang Perguruan Tinggi adalah prinsip kegiatan yang tujuannya tidak untuk mencari laba, sehingga seluruh sisa hasil usaha dari kegiatan harus ditanamkan kembali ke Perguruan Tinggi untuk meningkatkan kapasitas dan/atau mutu layanan pendidikan. Dengan demikian, berdasarkan penjelasan Pasal 60 UndangUndang Nomor 12 Tahun 2012 tentang Perguruan Tinggi, telah dapat dipastikan bahwa Perguruan Tinggi Swasta hanya dapat didirikan oleh badan hukum penyelenggara berbadan hukum yang berprinsip nirlaba. Oleh karenanya secara a contrario dapat dikonstruksikan bahwa pendirian perguruan tinggi tidak mungkin dapat didirikan oleh suatu badan usaha (baik Badan Usaha Milik Negara, Badan Usaha Milik Daerah, maupun Badan Usaha Swasta) yang tujuannya tidak lain adalah untuk mencari keuntungan yang sebanyakbanyaknya.

Berkaitan dengan pendirian perguruan tinggi yang salah satunya dapat dilakukan oleh badan penyelenggara yang berbentuk Yayasan; pada pasal 1 angka 1 Undangundang Nomor 16 Tahun 2001 Tentang Yayasan (Untuk selanjutnya disebut sebagai "UUY 16/2001), telah 
didefinisikan oleh pembentuk undangundang bahwa yang dimaksud dengan "Yayasan" adalah badan hukum yang terdiri atas kekayaan yang dipisahkan dan diperuntukkan untuk mencapai tujuan tertentu di bidang sosial, keagamaan, dan kemanusiaan, yang tidak mempunyai anggota. Pada definisi tentang Yayasan ini terlihat bahwa tujuan dari Yayasan bukanlah pencapaian keuntungan yang sebanyak-banyaknya, melainkan pencapaian tujuan tertentu di bidang sosial, keagamaan, dan kemanusiaan.

Dalam praktik, pencapaian tujuan tertentu di bidang sosial diantaranya dilakukan dengan mendirikan atau menyelenggarakan pendidikan formal (termasuk di dalamnya mendirikan perguruan tinggi) dan informal, rumah sakit, poliklinik, rumah duka, pelayanan pemakaman, pelayanan jenazah dan krematorium. Pencapaian tujuan tertentu di bidang keagamaan diantaranya dilakukan dengan mendirikan rumah ibadah, mendirikan retreat center dan wisma untuk pembinaan dan pelayanan kerohanian, dan lain-lain. Sedangkan pencapaian tujuan tertentu di bidang kemanusiaan diantaranya dilakukan dengan mendirikan rumah yatim piatu, rumah jompo, wisma tuna netra, membantu korban bencana alam, penampungan pengungsi, hak asasi manusia dan lingkungan hidup serta lain sebagainya.

Pembahasan mengenai Yayasan bukan sebagai badan usaha, dipertegas dalam Penjelasan Pasal 3 ayat (1) sebagaimana diubah dengan Undang-undang Nomor 28 Tahun 2004 Tentang Perubahan Atas Undang-undang Nomor 16 Tahun 2001 Tentang Yayasan (Untuk selanjutnya disebut sebagai "UUY 28/2004"); yang pada intinya menyebutkan bahwa Yayasan tidak digunakan sebagai wadah usaha dan tidak dapat melakukan kegiatan usaha secara langsung, tetapi harus melalui badan usaha yang didirikannya atau melalui badan usaha lain di mana Yayasan menyertakan kekayaannya. Hal ini merupakan konsekuensi logis, karena yayasan bukanlah badan usaha, akan tetapi diperkenankan untuk melakukan penyertaan modal pada suatu badan usaha dengan tetap memperhatikan persyaratan yang telah ditetapkan oleh peraturan perundang-undangan.

Berdasarkan ketentuan-ketentuan di atas, dapat dipastikan bahwa Yayasan adalah badan hukum, tetapi bukanlah termasuk sebagai badan usaha yang tujuannya digunakan untuk mencari keuntungan. Hal ini tentunya sangat berbeda dengan badan usaha, baik milik negara, milik daerah, maupun swasta yang digunakan sebagai wadah usaha dengan tujuan untuk mencari keuntungan sebanyak-banyaknya (terutama yang berbentuk badan hukum perseroan terbatas).

Pasal 17 huruf f UUJN eksplisit disebutkan adanya larangan bagi pengemban profesi Notaris untuk merangkap jabatan sebagai pemimpin atau pegawai badan usaha milik negara, badan usaha milik daerah atau badan usaha swasta. Pada kurun waktu tertentu, selama pengemban jabatan Notaris mengajar (menjadi dosen di suatu perguruan tinggi), sekalipun tidak ada perjanjian tertulis yang ditanda-tangani, dapatlah dikatakan telah ada suatu hubungan hukum yang berupa perikatan, yang terjadi antara orang-orang yang berprofesi sebagai Notaris tersebut dengan Yayasan di mana perguruan tinggi 
tersebut bernaung atau didirikan.

Sehubungan dengan Yayasan adalah badan hukum yang bukan suatu badan usaha sebagaimana diuraikan di atas; maka sekalipun antara Notaris dan pihak Yayasan ada suatu hubungan kerja dan ada pengupahan yang terjadi karenanya; maka tetap Notaris tersebut bukanlah pemimpin atau pegawai dari suatu badan usaha. Dengan demikian, Notaris yang memiliki jabatan rangkap sebagai Dosen / tenaga pengajar ataupun yang mengemban jabatan struktural dalam perguruan tinggi dengan mendapatkan surat keputusan pengangkatan atau menutup perjanjian kerja dan mendapatkan upah dari pekerjaan yang dijalaninya, dapat dipastikan dirinya tidak melakukan pelanggaran terhadap ketentuan mengenai larangan sebagaimana disebutkan dalam Pasal 17 huruf f UUJN. Selain itu, menjadi Dosen / tenaga pengajar atau mengemban jabatan struktural pada suatu perguruan tinggi tentunya tidak termasuk melakukan pekerjaan lain yang bertentangan dengan norma agama, kesusilaan, atau kepatutan yang dapat mempengaruhi kehormatan dan martabat jabatan Notaris sebagaimana yang diatur secara eksplisit pada Pasal 17 huruf i UUJN.

Demi kepastian hukum, sedikit menelaah lebih dalam mengenai jabatan rangkap dan pekerjaan apa yang boleh dilakukan oleh Notaris selain sebagai Dosen/Tenaga Pengajar (yang bukan Pegawai Negeri); A.A. Andi Prajitno ${ }^{7}$ dengan tegas menyebutkan bahwa:

"Jabatan yang boleh dirangkap:

1. Pejabat Pembuat Akta Tanah

\footnotetext{
${ }^{7}$ A.A. Andi Prajitno, Pengetahuan Praktis Tentang Apa dan Siapa Notaris Di Indonesia?, Surabaya: Putra Media Nusantara, 2010, hlm.78.
}

(PPAT),

2. Pejabat Lelang Kelas II,

3. Mediator sebagaimana dimaksud dalam Pasal 1 ayat (6) PERMA No. 01/2008,

4. Pengajar/dosen."

Pengembanan rangkap jabatan selaku Pejabat Pembuat Akta Tanah (PPAT) sebagaimana disebutkan pada angka 1 di atas, tentunya dimaksudkan yang daerah kerjanya sesuai dengan tempat kedudukan dari Notaris tersebut sebagaimana diatur dalam Pasal 18 ayat 1 UUJN. Pada angka 4 di atas disebutkan pula secara tegas bahwa jabatan yang boleh dirangkap oleh pengemban jabatan Notaris adalah pengajar/dosen; tentunya dimaksudkan bahwa pengajar/dosen tersebut bukanlah pengajar/dosen yang berstatus sebagai pegawai negeri (vide Pasal 17 huruf $\mathrm{c}$ UUJN). Jika dikonstruksikan secara $a$ contrario dari Pasal 17 huruf i UUJN; maka Notaris juga dapat melakukan pekerjaaan lain yang tentunya tidak bertentangan dengan: norma agama, kesusilaan, atau kepatutan yang dapat mempengaruhi kehormatan dan martabat jabatan Notaris. Berdasarkan analisis tersebut, Notaris tidak dilarang atau diperkenankan untuk mengemban jabatan rangkap sebagai dosen.

Setelah adanya kepastian hukum mengenai rangkap jabatan atau pekerjaan apa yang boleh dan tidak boleh diemban atau dikerjakan oleh Notaris; selanjutnya perdebatan yang mungkin timbul mengenai rangkap jabatan atau pekerjaan lain yang boleh diemban/dilakukan oleh Notaris 
biasanya dilanjutkan antara lain seputar: waktu aktivitas yang digunakan untuk melakukan kegiatan lain yang tidak termasuk kegiatan kenotariatan dan tempat aktivitas yang tidak dilakukan di kantornya sendiri.

Adapun mengenai penggunaan waktu yang dialokasikan oleh Notaris dan tempat pelaksanaan aktivitas yang tidak terkait dengan aktivitas kenotariatan yang dilakukan di luar kantornya karena dirinya merangkap jabatan sebagai dosen atau tenaga pengajar, dapat dijelaskan bahwa: selama masyarakat yang membutuhkan layanannya sebagai Notaris dalam hal pembuatan akta otentik masih dapat terlayani dengan baik; maka seyogyanya, penggunaan waktu dan tempat aktivitas dalam melaksanakan tugasnya sebagai dosen bukanlah merupakan pelanggaran. Pelaksanaan dari hal tersebut tentunya dilakukan dengan catatan selama dirinya tidak meninggalkan wilayah jabatannya lebih dari 7 (tujuh) hari kerja berturut-turut sebagaimana diatur dalam Pasal 17 huruf $b$ UUJN.

Bila "adu argumen" mengenai penggunaan waktu dan tempat aktivitas karena pengemban jabatan Notaris melakukan rangkap jabatan sebagai Dosen/tenaga pengajar masih terus dilakukan; maka secara konsisten, perdebatan mengenai penggunaan waktu dan tempat aktivitas tersebut kemungkinan dapat juga diteruskan dengan perdebatan yang tidak ada henti-hentinya mengenai bagaimana dengan Notaris yang membacakan akta Perjanjian Kredit dan Akta Pemberian Hak Tanggungan atau akta-akta lain bukan di kantornya tetapi masih dalam wilayah jabatannya dengan penggunaan waktu aktivitas yang terkadang tidak sebentar, bagaimana dengan Notaris yang memiliki salon, toko kue, percetakan, bengkel motor, bagaimana dengan Notaris yang melakukan rangkap jabatan sebagai Pejabat Pembuat Akta Tanah (PPAT), bagaimana dengan Notaris yang merangkap jabatan menjadi Pejabat Lelang Kelas II dan Mediator yang melaksanakan tugasnya di luar kantorNotaris-nya, atau melakukan pekerjaan lain yang diperkenankan atau tidak bertentangan dengan larangan rangkap jabatan sebagaimana diatur dalam Pasal 17 huruf c, d, e, f, g, h, dan i UUJN.

Pengaturan yang khususnya mengatur mengenai larangnan dan kebolehan rangkap jabatan di atas dapat dikaji berdasarkan cita-hukum Pancasila sebagai alat uji terhadap hukum positif yang berlaku, dan pengarah hukum positif sebagai usaha mengatur tata kehidupan masyarakat dan bangsa. Cita-hukum Pancasila merupakan gagasan, rasa, karsa, cipta dan pikiran berkenaan dengan hukum atau persepsi tentang makna hukum, yang dalam intinya terdiri atas tiga unsur: keadilan, kehasil-gunaan (doelmatigheid) dan kepastian hukum.

Notaris yang merangkap jabatan sebagai dosen tidak memunculkan ketidakadilan baik diantara para Notaris lain yang tindak merangkap menjadi dosen, maupun terhadap dosen yang tidak merangkap jabatan sebagai Notaris. Semuanya akan dilakukan dan ditempatkan sesuai porsinya masing-masing. Notaris yang merangkap menjadi dosen bahkan dapat memberikan kontribusi yang antara lain adalah adanya pendekatan dan pemahaman yang seimbang antara dunia keilmuan hukum dengan dunia praktik hukum pada kenyataannya, antara das sollen dengan das 
sein. Para peserta didik diharapkan mendapatkan pemahaman antara lain mengenai: apa yang menjadi kaidah hukum dan fakta hukumnya, bagaimana hukum diterapkan pada suatu kondisi tertentu, bagaimana penegak dan pelaku hukum dalam melaksanakan hukum, serta bagaimana masyarakat merespon hukum tersebut, dan lain sebagainya. Hal ini tentunya memenuhi unsur kehasil-gunaan (doelmatigheid). Pasal 17 huruf c, d, e, f, g, h, dan i UUJN No. 2/2014 telah memberikan kepastian hukum mengenai rangkap jabatan yang dilarang untuk diemban oleh pengemban profesi Notaris.

\section{PENUTUP}

Pengembanan jabatan rangkap Notaris yang dilarang adalah jabatan rangkap yang bertentangan dengan Pasal 17 huruf c, d, e, f, g, h, dan i UUJN No. 2/2014 serta Kode Etik Ikatan Notaris Indonesia. Pengembanan jabatan rangkap baik sebagai Notaris maupun juga sebagai dosen atau tenaga pengajar di suatu perguruan tinggi atau fakultas hukum atau program pasca sarjana dapat dibenarkan atau tidak melanggar UUJN dan Kode Etik Ikatan Notaris Indonesia sepanjang perguruan tinggi tersebut berbentuk atau didirikan oleh badan hukum Yayasan (bukan didirikan atau berbentuk badan usaha milik negara, badan usaha milik daerah, atau badan usaha swasta) dan/atau Notaris tersebut tidak merangkap jabatan sebagai (dosen yang berstatus) pegawai negeri. Notaris yang menjadi dosen atau tenaga pengajar, tidak dapat dianggap atau dimasukan dalam kategori sebagai melakukan pekerjaan lain yang bertentangan dengan norma agama, kesusilaan, atau kepatutan yang dapat mempengaruhi kehormatan dan martabat jabatan Notaris. Menurut hemat penulis, menjadi dosen atau tenaga pengajar adalah melakukan pekerjaan lain yang bahkan bila dijiwai dan dilakukan secara baik dan benar dapat meningkatkan kehormatan dan martabat jabatan Notaris itu sendiri

\section{DAFTAR PUSTAKA}

\section{Buku}

A.A. Andi Prajitno, Pengetahuan Praktis Tentang Apa dan Siapa Notaris Di Indonesia?, Surabaya: Penerbit Putra Media Nusantara, 2010.

Herlien Budiono, Kumpulan Tulisan Hukum Perdata di Bidang Kenotariatan, Buku Kedua, Bandung: Citra Aditya Bakti, Bandung, 2010

Santia Dewi dan R.M. Fauwas Diradja, Panduan Teori dan Praktik Notaris, Yogyakarta: Penerbit Pustaka Yustisia, 2011.

Sjaifurrachman, Aspek

Pertanggungjawaban Notaris dalam

Pembuatan Akta, Bandung: Mandar Maju, Bandung, 2011.

\section{Perundang-Undangan}

Kitab Undang-undang Hukum Perdata;

Undang-undang Nomor 16 Tahun 2001 Tentang Yayasan

Undang-undang Nomor 28 Tahun 2004 Tentang Perubahan atas Undangundang Nomor 16 Tahun 2001 Tentang Yayasan

Undang-undang Nomor 30 Tahun 2004

Tentang Jabatan Notaris

Undang-undang Nomor 12 Tahun 2012

Tentang Pendidikan Tinggi

Kode Etik Notaris Indonesia. 